\title{
INDOOR CLIMATIC STATUS DURING WINTER CONDITIONS IN DAIRY HERDS IN BOSNIA AND HERZEGOVINA
}

\author{
Miljan ERBEZ ${ }^{1,2}$, Božo VAŽIĆ ${ }^{3}$, Knut Egil BØE ${ }^{4}$, Lars Erik RUUD ${ }^{5}$
}

Received November 14, 2016; accepted December 28, 2016. Delo je prispelo 14. novembra 2016, sprejeto 28. decembra 2016.

\section{Indoor climatic status during winter conditions in dairy herds in Bosnia and Herzegovina}

The aim of this cross-sectional field study was to describe climatic status in dairy barns during winter conditions both in lowland and in mountainous regions of Bosnia and Herzegovina. While all the mountain herds had tie-stall systems (MT), eight of the lowland herds had group housing systems (LG) and the remaining 30 herds had tie-stall systems (LT). The mean indoor air temperature $\left(\mathrm{T}_{\mathrm{i}}\right)$ was around $10^{\circ} \mathrm{C}$ across types of barns and in all herds $\mathrm{T}_{\mathrm{i}}$ was above $0{ }^{\circ} \mathrm{C}$. The mean relative air humidity ( $\mathrm{RH})$ was actually highest in the LT-group, but within the recommended level for both LG, LT and MT barns. At the $15 \%$ of the MT barns, $17 \%$ of the LT barns and $38 \%$ of the LG barns the air velocity was $>0.2 \mathrm{~m} / \mathrm{s}$. The level of $\mathrm{NH}_{3}$ was quite low in all groups of barns, although somewhat higher in LT-barns. In none of the barns the level of $\mathrm{NH}_{3}$ exceeded $3 \mathrm{ppm}$. Only in one barn (a MT-barn) the level of $\mathrm{CO}_{2}$ exceeded $3000 \mathrm{ppm}$. We conclude that the climatic status in most dairy barns in Bosnia and Herzegovina during winter seem to be acceptable.

Key words: cattle; dairy cows; housing; climatic status; air velocity; carbon dioxide; ammonia; winter; Bosnia and Herzegovina

\section{INTRODUCTION}

The dairy sector in Bosnia and Herzegovina (BiH) is based mostly on small scale farms, with most herds smaller than five dairy cows (Loza, 2014). Tie-stall system is commonly used on most farms, whereas group housing is rare and only used on a few larger farms. In

\section{Zimske klimatske razmere vobjektih za krave molznice v Bosni in Hercegovini}

Namen te presečne študije je bil opisati klimatske razmere v objektih za krave molznice $\mathrm{v}$ zimskem času $\mathrm{v}$ nižinskih in hribovskih območjih Bosne in Hercegovine. $\mathrm{V}$ vseh čredah v hribovskih območjih smo našli vezano rejo (MT), medtem ko so imeli v osmih čredah v nižinskem predelu skupinsko uhlevitev (LG), v preostalih 30 čredah pa vezano rejo (LT). Povprečna temperature zraka v objektih $\left(\mathrm{T}_{\mathrm{i}}\right)$ je bila okrog $10^{\circ} \mathrm{C}$ in $\mathrm{v}$ vseh čredah so bile temperature $\mathrm{T}_{\mathrm{i}}$ nad $0^{\circ} \mathrm{C}$. Povprečna relativna vlaga (RH) je bila najvišja v skupini LT, vendar še znotraj priporočenih vrednosti, tako $\mathrm{v}$ LG in LT, kot tudi v MT hlevih. V $15 \%$ MT hlevov, 17 \% LT hlevov in 38 \% LG hlevov je hitrost zraka presegala $0,2 \mathrm{~m} / \mathrm{s}$. Koncentracija $\mathrm{NH}_{3}$ je bila v vseh hlevih relativno nizka, le v LT hlevih je bila nekoliko višja. V nobenem od hlevov koncentracija $\mathrm{NH}_{3}$ ni presegla $3 \mathrm{ppm}$. Samo v enem MT hlevu je koncentracija $\mathrm{CO}_{2}$ presegla $3000 \mathrm{ppm}$. Na osnovi teh podatkov sklepamo, da so klimatske razmere $\mathrm{v}$ večini hlevov za molzne krave v Bosni in Hercegovini v zimskem času ustrezne.

Ključne besede: govedo; krave; molznice; uhlevitev; klimatske razmere; hitrost zraka; ogljikov monoksid; amonijak; zima; Bosna in Hercegovina

many of the old tie-stall barns, mangers are directed to the walls and openings in the ceiling to the hay storage above the animal room which may contribute to air exchange. Poor building design and unsuitable microclimate may result in decreased productivity, diseases and risks to animal welfare (Cena and Clark, 1981; Charles, 1981).

\footnotetext{
1 University of Banja Luka, Faculty of Agriculture, Bulevar vojvode Petra Bojovića 1A, Banja Luka 78000, Republic of Srpska, Bosnia and Herzegovina

2 Corresponding author, e-mail: miljanerbez@gmail.com

3 Same address as 1, e-mail: vazicb@yahoo.com

4 Norwegian University of Life Science, Faculty of Veterinary Medicine and Biosciences, Campus Ås, Universitetstunet 3, 1433 Ås, Norway, e-mail: knut.boe@nmbu.no

5 Hedmark University of Applied Sciences, Faculty of Applied Ecology and Agricultural Sciences, P.O. Box 400, 2418 Elverum, Norway, e-mail: lars.ruud@hihm.no
} 
The intensive dairy production in $\mathrm{BiH}$ is located in the northern lowland region (<300 m.a.s.l.) and less intensive production is found in the central and southern mountainous regions (> 600 m.a.s.l.). In the northern lowland region the mean air temperature in January is approximately $-1{ }^{\circ} \mathrm{C}$ and in the central and southern mountainous regions the mean air temperature ranges from -4 to $-7^{\circ} \mathrm{C}$ (UNFC, 2013). The cows are usually kept on pasture for 7 to 8 months during summer.

Normally the winter ventilation is regulated to control moisture and gases (Curtis, 1981). Many older dairy barns in $\mathrm{BiH}$ are often without adequate ventilation, meaning that concentration of moisture, $\mathrm{CO}_{2}$ and probably also $\mathrm{NH}_{3}$ may be higher than recommended during winter time.

Recommended indoor temperature for dairy cattle during winter are 5 to $10{ }^{\circ} \mathrm{C}$ (CIGR, 1999), whereas maximum recommended $\mathrm{RH}$ is temperature dependent (CIGR, 1999). Recommended maximum $\mathrm{RH}$ at $10^{\circ} \mathrm{C}$ is $80 \%$, and the implication of the CIGR-recommendation is that the sum of indoor temperature and $\mathrm{RH}$ should be lower than 90 (CIGR, 1999; Ruud et al., 2014). It is also recommended that concentration of ammonia and carbon dioxide should not exceed 25 ppm (Weeks, 2008) and 3000 ppm (CIGR, 1999), respectively. Even low concentrations of ammonia are considered to endanger health (Danuser et al., 1988; Brautbar et al., 2003). High air velocity will increase the animal heat loss, and the air velocity in the animal zone during winter should therefore not exceed $0.2 \mathrm{~m} / \mathrm{s}$ (Poulsen and Pedersen, 2009). Larger indoor room volume per animal is positive for air quality (Poulsen and Pedersen, 2009), and at least $18 \mathrm{~m}^{3}$ per cow is recommended in loose housing systems (Anonymous, 2001; Ruud et al., 2014).

The design of farm buildings, including ventilation, are influenced by local traditions, however, the detailed knowledge of indoor climate in $\mathrm{BiH}$ is scarce. Hence, the aim of this cross-sectional field study was to describe climatic status in dairy barns during winter conditions both in lowland and in mountainous regions of $\mathrm{BiH}$.

\section{MATERIALS AND METHODS}

\subsection{SELECTION OF HERDS}

A total of 76 commercial dairy herds in $\mathrm{BiH}$ were randomly selected from the Register of agricultural producer's database (www.apif.net). Half of the herds $(n=38)$ were selected from a geographical area that were located lower than 300 meter above sea level and the other half of the herds $(n=38)$ were selected from a geographical area that were located higher than 600 meter above sea level. While all the mountain herds had tie-stall systems (MT), eight of the lowland herds had group housing systems (LG) and the remaining 30 herds had tie-stall systems (LT). Five of the LG herds had cubicles and three of the herds had deep bedding in the lying area.

\subsection{HERD CHARACTERISTICS AND BREEDS}

Mean herd size for the MT herds was the smallest, somewhat larger in LT farms and the largest was in LG herds (Table 1). The main breed on the farms in the study were Simmental (42 farms), Gacko cattle (27 farms) and Holstein (7 farms).

All the MT, $53 \%$ of the LT and $25 \%$ of the LG herds practiced summer grazing, and the mean grazing period for all herds practicing grazing was 7.5 months.

\subsection{BARNS AND VENTILATION SYSTEMS}

During the indoor feeding period from December 2013 to February 2014, all the 76 herds were visited once by a team of trained observers. The herds were visited at daytime between 7:30 and 15:00 hours. A systematic protocol was used to record data on each farm. This protocol was an adapted version of that one used in the Norwegian KUBYGG-project (Simensen et al., 2010).

Most of barns in the mountain regions were older buildings with solid stone walls and with small windows

Table 1: Herd characteristics for 76 mountain and lowland dairy herds (total range in brackets)

Preglednica 1: Značilnosti 76 hribovskih in nižinskih čred molznic (v oklepajih so navedene ekstremne vrednosti)

\begin{tabular}{lclc}
\hline Herd characteristics/groups & Lowland group housing (LG) & Lowland tie-stall (LT) & Mountain tie-stall (MT) \\
\hline Number of herds & 8 & 30 & 38 \\
Mean herd size, dairy cows ${ }^{1}$ & $51.4(21-107)$ & $16.2(6-54)$ & $11.9(5-74)$ \\
Mean herd size, all animals ${ }^{1}$ & $95.8(23-165)$ & $25.0(6-110)$ & $18.0(6-118)$ \\
Mean floor area $\left(\mathrm{m}^{2} / \mathrm{animal}\right)$ & $7.8(4.4-12.5)$ & $7.6(3.5-13)$ & $6.5(2.5-28.2)$ \\
Mean barn air volume $\left(\mathrm{m}^{3} / \mathrm{animal}\right)$ & $53.0(26.8-115.7)$ & $29.18(10.5-85.3)$ & $25.6(5.1-198.7)$ \\
\hline
\end{tabular}

${ }^{1}$ Represents number of animals in the room where the measurements were performed 
in the outer walls that could be manually regulated as the only air inlet. These buildings had no specific air outlet, but had openings in the ceiling to the hay storage above the animal room contributing to the air exchange. Eighteen of MT barns had windows closed at the observation day, 6 were half opened and 14 opened.

LT barns were in majority also older buildings with solid walls of brick or wood and with ventilation windows as air inlet. Ten of the LT barns had open ridge for air outlet, whereas 20 had a solid ceiling with no special air outlet. Thirteen of LT barns had windows closed at the observation day, 16 were half opened and 1 opened.

The eight LG barns were in general newer, often built in the last decade. LG barns had open side walls with or without curtains as air inlets. Five of these barns had ridge openings for air outlet.

The dimensions of the main animal room were recorded using a laser distance meter (LDM50, PCE instruments, UK). Based on these numbers, total space per animal and total air volume per animal were calculated (Table 1). Mean floor area per animal did not differ much between the herd categories, but mean air volume per animal was higher in group housed herds than in the tie-stall barns.

On all farms, the manure was scraped out from the building and kept in outside lagoons or in a pile.

\subsection{INDOOR CLIMATE}

Indoor air temperature $\left(\mathrm{T}_{\mathrm{i}}\right)$ and air velocity was measured at 3 locations inside each barn; at the north side of the barn, middle and south side and also air temperature outside ( $\mathrm{T}_{0}$ ), using PCE-423 (PCE Instruments, UK). Relative air humidity $(\mathrm{RH})$ was measured at the same locations inside the barn using PCE-AM 82 (PCE Instruments, UK). Carbon dioxide $\left(\mathrm{CO}_{2}\right)$ and ammonia $\left(\mathrm{NH}_{3}\right)$ was measured in the center of each animal room using IBRID MX6 (Industrial Scientific Corporation, USA).

\subsection{STATISTICAL ANALYSIS}

In order to test the effect of housing system on climatic variables, a one-way ANOVA test was performed using Excel 2013 (Microsoft), and with a significance level of $p \leq 0.05$. Two herds with a room volume higher than $90 \mathrm{~m}^{3}$ /animal were removed from the dataset when calculating room volume. Paired $t$-tests were used for pairwise comparisons between arithmetical means for different climatic parameters in the three groups of dairy barns.

\section{RESULTS}

As could be expected, the mean outdoor air temperature $\left(\mathrm{T}_{\mathrm{o}}\right)$ was lower for the mountain herds than for the lowland herds (Table 2), and outdoor temperatures below $0{ }^{\circ} \mathrm{C}$ was only found at mountain herd locations.

The mean indoor air temperature $\left(\mathrm{T}_{\mathrm{i}}\right)$ was around $10{ }^{\circ} \mathrm{C}$ across types of barns and in all herds $\mathrm{T}_{\mathrm{i}}$ was above $0{ }^{\circ} \mathrm{C}$ (Table 2). $\mathrm{T}_{\mathrm{i}}$ somewhat lower in the MT-barns, and the variation within this type of barn was higher.

The mean relative air humidity $(\mathrm{RH})$ was actually highest in the LT-group (Table 2), but within the recommended level for both LG, LT and MT barns. However, among the LT and MT barns there were some barns with $\mathrm{RH}>90 \%$.

Only in LT barns, the mean sum of indoor temperature and $\mathrm{RH}$ was higher than 90 (Table 2), and 17 of the 30 barns had a $\mathrm{T}_{\mathrm{i}}+\mathrm{RH}$ value higher than 90 . In MT barns, eight of 38 herds had a $\mathrm{T}_{\mathrm{i}}+\mathrm{RH}$ value higher than 90 .

The mean air velocity was low in all groups of barns (Table 2). At the $15 \%$ of the MT barns, $17 \%$ of the LT barns and $38 \%$ of the LG barns the air velocity was $>0.2 \mathrm{~m} / \mathrm{s}$. The highest air velocity measured was only $0.67 \mathrm{~m} / \mathrm{s}$.

Table 2: Mean and range for different climatic parameters in the three groups of dairy barns

Preglednica 2: Povprečja in ekstremne vrednosti različnih klimatskih parametrov v treh tipih hlevov za molznice.

\begin{tabular}{|c|c|c|c|c|c|}
\hline & $\begin{array}{l}\mathrm{LG} \\
\mathrm{n}=8\end{array}$ & $\begin{array}{l}\mathrm{LT} \\
\mathrm{n}=30\end{array}$ & $\begin{array}{l}\text { MT } \\
\mathrm{n}=38\end{array}$ & $\mathrm{~F}$ & $\mathrm{P}$ \\
\hline Outdoor air temperature $\left({ }^{\circ} \mathrm{C}\right)$ & $8.6^{\mathrm{a}}(3.3-12.7)$ & $9.6^{\mathrm{a}}(4.4-15.1)$ & $5.0^{\mathrm{b}}(-5.0-17.0)$ & 9.48 & $<0.001$ \\
\hline Indoor air temperature $\left({ }^{\circ} \mathrm{C}\right)$ & $9.2^{\mathrm{ab}}(3.1-14.1)$ & $11.7^{\mathrm{a}}(6.5-17.5)$ & $8.5^{\mathrm{b}}(1.6-18.1)$ & 7.08 & $<0.002$ \\
\hline Relative air humidity (\%) & $67.3^{\mathrm{a}}(51.1-79.5)$ & $78.6^{\mathrm{b}}(59.2-92.9)$ & $72.2^{\mathrm{a}}(50.9-99.1)$ & 5.91 & $<0.005$ \\
\hline Sum $\mathrm{Ti}+\mathrm{RH}$ & $76.4^{\mathrm{a}}(66.2-87.1)$ & $90.3^{\mathrm{b}}(74.5-102,6)$ & $80.8^{\mathrm{a}}(55.4-108.7)$ & 10.26 & $<0.001$ \\
\hline Air velocity (m/s) & $0.14(0.04-0.31)$ & $0.13(0.01-0.67)$ & $0.07(0.01-0.45)$ & 1.44 & $=0.24$ \\
\hline $\mathrm{NH}_{3}(\mathrm{ppm})$ & $1.13^{\mathrm{ab}}(0-2)$ & $1.46^{\mathrm{a}}(0-3)$ & $1.0^{\mathrm{b}}(0-2)$ & 3.93 & $<0.05$ \\
\hline $\mathrm{CO}_{2}(\mathrm{ppm})$ & $627.5(390-890)$ & $936.7(390-1690)$ & $1105.7(390-5390)$ & 1.82 & $=0.16$ \\
\hline
\end{tabular}

${ }^{\mathrm{a}, \mathrm{b}}$ Means with different superscripts differ significantly $(p<0.05)$ 
The level of $\mathrm{NH}_{3}$ was quite low in all groups of barns (Table 2), although somewhat higher in LT-barns. In none of the barns the level of $\mathrm{NH}_{3}$ exceeded $3 \mathrm{ppm}$. There was no significant differences between groups of barns regarding concentration of $\mathrm{CO}_{2}$. Only in one barn (a MTbarn) the level of $\mathrm{CO}_{2}$ exceeded 3000 ppm.

The mean room volume was lowest in MT barns (25.6 $\mathrm{m}^{3}$ /animal), somewhat higher in the LT barns $\left(29.2 \mathrm{~m}^{3} /\right.$ animal $)$ and highest in the LG barns $\left(53.0 \mathrm{~m}^{3} /\right.$ animal). A total of $76.3 \%$ of MT barns, $40 \%$ of the LT barns and none of the LG barns had a room volume lower than $18 \mathrm{~m}^{3}$ /animal.

\section{DISCUSSION}

Even during the winter months the outdoor temperatures was relatively modest in both lowland and mountainous regions. These conditions did not challenge the animal thermoregulation (Young, 1981). In addition the animals were kept inside under partly controlled climate conditions where the air temperature was even higher. Air velocity will increase animal heat loss (CIGR, 1999), but generally air velocity was low. Even if the air velocity was $0.67 \mathrm{~m} / \mathrm{s}$ in one herd, this will not be critical for the animals.

The mean relative humidity and $\mathrm{CO}_{2}$ was well within recommended levels (CIGR, 1999; Ruud et al., 2014). $\mathrm{RH}$ was higher in the LT barns, but there were no differences between groups concerning $\mathrm{CO}_{2}$. This may seem strange for MT and LT farms, because those did not have a specially designed ventilation system.

In the MT barns the air evacuation in to the hay storage room above seems to have satisfactory function as ventilation system, since that levels of $\mathrm{RH}$ and $\mathrm{CO}_{2}$ are within recommended levels on most farms (CIGR, 1999; Ruud et al., 2014). Small windows in MT barns seem to have a low effect, since no difference were found whether windows were open or closed.

The lowest level of $\mathrm{RH}$ and $\mathrm{CO}_{2}$ was found in the LG barns, which seem logical since these barns had a dedicated ventilation system with open side walls, ridge openings and in addition a large barn volume. In the LT barns we found highest $\mathrm{T}_{\mathrm{i}}, \mathrm{RH}$ and $\mathrm{T}_{\mathrm{i}}+\mathrm{RH}$. This may be due to the solution with the solid roof and construction with no dedicated air outlet. As this is the most common type of building for dairy cattle in $\mathrm{BiH}$, further studies should be especially focused on this type of buildings. The $\mathrm{NH}_{3}$ level was generally low which could be due to that manure and urine was removed from the room around two times daily. No manure was stored in direct connection with the animal room.

\section{CONCLUSION}

The lowest variation among the followed parameters were in LG barns which had specialized air inlets and outlets. It is to conclude that LG barns, are more suitable for intensive and profitable dairy production in climatic conditions of $\mathrm{BiH}$. The building constructions being used in $\mathrm{BiH}$ seem to work quite well regarding indoor climatic conditions, however focus should also be kept on management routines especially in high yielding herds. We conclude that the climatic status in most dairy barns in Bosnia and Herzegovina during winter seem to be acceptable.

\section{ACKNOWLEDGEMENTS}

The authors thank the participating farmers, the master students Vanja Jovovic and Aleksandar Maric, as well as the people at MAFWRS for their helpfullness during the study. We also appreciates the good cooperation we had with Biljana Rogić from the University of Banja Luka, Tatjana Pandurević from the University of East Sarajevo and Vinko Batinic from the University of Mostar. The study was financially supported by the Norwegian HERD programme (grant ref. no. $332160 \mathrm{UU}$ ).

\section{REFERENCES}

Anonymous. (2001). Interdisciplinary report "Housing Design for Cattle - Danish Recommendations. Third edition 2001. The Danish Agricultural Advisory Center. Translated into English and issued in 2002. 122 p.

Brautbar, N., Wu, M. P., \& Richter, E. (2003). Chronic ammonia inhalation and interstitial pulmonary fibrosis: a case report and review of the literature. Archive of environmental health, 58, 592-596. doi:10.3200/AEOH.58.9.592-596

Cena, K. M., \& Clark, J. A. (1978). Thermal resistance units. Journal of Thermal Biology, 3, 173- 174. doi:10.1016/03064565(78)90014-1

Charles, D. R. (1981). Practical ventilation and temperature control for poultry. In: J. A. Clark (Ed.), Environmental Aspects of Housing for Animal production (pp. 309-330). London: Butterworths. doi:10.1016/B978-0-408-106887.50017-5

CIGR. (1999). Animal production \& aquacultural engineering. In E. H., Bartali, A. Jongebreur, \& D. Moffitt (Eds.), CIGR Handbook of agricultural engineering (Vol. II). St. Joseph, USA: American Society of Agricultural Engineers (ASAE).

Danuser, B., Wyss, C., \& Hauser, R. (1988). Lung function and symptoms in poultry farmers. Social and preventive medicine, 33(6), 286-291. doi:10.1007/BF02106784

Loza, D. (2014). Milk processing in Bosnia-Herzegovina 
in 2013. Sarajevo: Milkprocessing d.o.o., Konsalting i inženjering u stočarstvu.

Poulsen, H., \& Pedersen, S. (2009). Klimateknik. Århus, Denmark: Landbrugsforlaget, Danish agricultural advisory services.

Ruud, L. E., Stokke, T., Bøe, K. E., Hettasch, T., \& Skjølberg, P. O. (2014). Hus for storfe - Norske anbefalinger (Norwegian recommendations for dairy housing). Ås, Norway: Norwegian cattle health services.

Simensen, E., Østerås, O., Bøe, K. E., Kielland, C., Ruud, L. E., \& Næss, G. (2010). Housing system and herd size interactions in Norwegian dairy herds; associations with per- formance and disease incidence. Acta Vetarinaria Scandinavica 52, 14. doi:10.1186/1751-0147-52-14

UNFC. (2013). Second national communication of Bosnia and Herzegovina under the United Nations framework convention on climate changes, was adopted by the Council of Ministers of $\mathrm{BiH}$ on 08 October 2013.

Young, B. A. (1981). Cold Stress as it Affects Animal Production. Journal of Animal Science, 52, 154-163. doi:10.2527/ jas $1981.521154 \mathrm{x}$

Weeks, C. A. (2008). A review of welfare in cattle, sheep and pig lairages, with emphasis on stocking rates, ventilation and noise. Animal welfare, 17(3), 275-284. 